\title{
'It Would Be without Error': Automated Technology and the Pursuit of Correct Performance in the French Enlightenment
}

\section{Rebecca Cypess}

To cite this article: Rebecca Cypess (2017) 'It Would Be without Error': Automated Technology and the Pursuit of Correct Performance in the French Enlightenment, Journal of the Royal Musical Association, 142:1, 1-29, DOI: 10.1080/02690403.2017.1286115

To link to this article: http://dx.doi.org/10.1080/02690403.2017.1286115

曲 Published online: 08 May 2017.

Submit your article to this journal $\widetilde{ }$

Џ Article views: 90

Q View related articles $\longleftarrow$

View Crossmark data ¿

Citing articles: 1 View citing articles $\sqsubset$ 


\title{
'It Would Be without Error': Automated Technology and the Pursuit of Correct Performance in the French Enlightenment
}

\author{
REBECCA CYPESS
}

\begin{abstract}
When Marie-Dominique-Joseph Engramelle published his treatise La tonotechnie, ou l'art de noter les cylindres (1775), he boasted that his method of pinning cylinders for use in automated musical instruments would offer composers a means of preserving their own performance practice and conception of their music for future generations, 'transmitting for posterity the proof of their genius without any alteration'. ${ }^{1}$ Listeners, in turn, would have seemingly direct access to the great French composers, and would no longer require unreliable performers to act as intermediaries. Engramelle ridiculed performers with bad taste, who 'disfigured' the works of towering composers of the past, including Jean-Baptiste Lully, JeanPhilippe Rameau and François Couperin. Valorizing his automated technology, he asked: 'Would it not be better to hear the same thing many times, if it were good, than to have the ears perpetually tormented by a mediocre organist?'2
\end{abstract}

Email: rcypess@mgsa.rutgers.edu

A version of this article was presented at the conference 'Expressive Engines: Musical Technologies from Automata to Robots', held at Mason Gross School of the Arts, Rutgers University, on 15 February 2016. I am grateful to Steven Kemper for his collaboration on that conference and for encouraging my interest in early modern automation, and to Michele Marinelli and Jere Ryder of the Murtogh D. Guinness Collection of Mechanical Musical Instruments and Automata, Morris Museum, Morristown, New Jersey, for their willingness to discuss Engramelle and his technology with me. My thanks are due as well to Rebecca Dowd Geoffroy-Schwinden and to the anonymous readers for this journal, whose insightful questions and comments improved the article greatly.

1 'Transmettre à la postérité des preuves de leur génie sans aucune altération'. Marie-DominiqueJoseph Engramelle, La tonotechnie, ou l'art de noter les cylindres (Paris, 1775; facsimile edn, Paris, 1993), 7. Original spellings, accents and italics have been retained in transcriptions of eighteenthcentury sources, but capitalizations have been standardized. Translations are mine unless otherwise indicated.

2 'Ne vaudroit-il pas mieux entendre plusieurs fois la même chose, si elle étoit bonne, que d'avoir perpétuellement les oreilles tourmentées par un médiocre organiste?' Ibid., 65. 
Engramelle was not alone in the French Enlightenment in viewing transmission of the composer's intentions as the ultimate aim of musical performance. ${ }^{3}$ Jean-Jacques Rousseau summarized this point clearly: 'What should be the primary concern of a musician in performance? Without doubt it is to enter into the spirit of the composer, and to appropriate his ideas so as to render them with all the fidelity that befits the taste of the piece.' ${ }^{4}$ Numerous writers on aesthetics and performance practice agreed that there was, in fact, a 'correct' manner of playing a given piece that originated with the composer; the work as an idea could not simply or easily be separated from the work as a performance. ${ }^{5}$ Yet, as is well known, music of the French Baroque was also widely described as encompassing a certain level of subjectivity - especially in its mouvement, its approach to tempo and temporal fluctuations. The 'correct' interpretation of a musical composition was one that captured the proper balance between precision and nonchalance, between freedom and good taste. ${ }^{6}$ All of these elements were, in the imagination of French thinkers, epitomized in the 'true intentions' of the composer, who was often also a performer. As Engramelle complained, the difficulty lay in the

${ }^{3}$ Nowhere in eighteenth-century sources do we find the sort of hand-wringing over the validity of the composer's intentions as a motivation for performance that has dominated so much of the discourse surrounding 'authenticity' and the historical performance movement since the 1990s. The classic modern-day statements on this subject are in Richard Taruskin, Text and Act: Essays on Music and Performance (Oxford and New York, 1995); among the most significant responses is Bruce Haynes, The End of Early Music: A Period Performer's History of Music (New York, 2007).

4 'Quelle doit être la grande attention du musicien dans l'exécution? C'est sans doute d'entrer dans l'esprit du compositeur, $\&$ de s'approprier ses idées pour les rendre avec toute la fidélité qu' exige le goût de la pièce.' Jean-Jacques Rousseau, Dissertation sur la musique moderne (Paris, 1743), 83.

5 This observation, on which I will expand in the discussion below, complicates the picture of the 'work concept' in music before 1800 put forth in Lydia Goehr, The Imaginary Museum of Musical Works: An Essay in the Philosophy of Music (Oxford, 1992), Chapter 7: 'Musical Production without the Work Concept' (pp. 176-204). It is well known that the performance of music before 1800 involved fluidity and flexibility in many respects. Among these are ornamentation, which was often added extemporaneously, and instrumentation in chamber works. Despite flexibility in matters such as these, however, the emotional content of a piece - its essential affect - would still demand that it be played with a 'correct' tempo and basic articulation, even if there was widespread disagreement among writers and players about what the correct solution was. Determination of a work's proper tempo was based on time signature, tempo markings, Notenbild, key and overall affective content, as described in numerous treatises on performance and composition from the eighteenth century, including those of Carl Philipp Emanuel Bach, Johann Philipp Kirnberger, Johann Joachim Quantz, Daniel Gottlob Türk and others. In earlier music, too, the ideal tempo was a function of mensuration sign, subdivisions of the beat and other essential factors. For a survey of these issues in eighteenth-century music, see Sandra P. Rosenblum, Performance Practices in Classic Piano Music: Their Principles and Applications (Bloomington, IN, 1986), Chapter 9: 'Choice of Tempo' (pp. 305-61). On tempo in earlier music, see George Houle, Meter in Music, 1600-1800: Performance, Perception, and Notation (Bloomington, IN, 1987), and Houle, 'Meter and Tempo', A Performer's Guide to Seventeenth-Century Music, ed. Stewart Carter, rev. and expanded by Jeffery Kite-Powell, 2nd edn (Bloomington, IN, 2012), 347-67.

${ }^{6}$ On changing notions of le bon goût, see Georgia Cowart, The Origins of Modern Music Criticism (Ann Arbor, MI, 1981). 
nature of music as a time-bound art; once a composer died, it was difficult not to let the composer's intentions with respect to performance die as well.

Musical notation was a poor vehicle for the preservation of those intentions. While it captured pitches, some ornaments and basic metrical and rhythmic patterns, it could hardly convey the fluidity and flexibility of execution that was encompassed by the aesthetic ideal of mouvement. ${ }^{7}$ In the eyes and ears of Engramelle, Denis Diderot and other thinkers of the Enlightenment, great musical traditions of the past were being lost to time, with notated music offering little more than a sketch of this lost ideal. It is within this context that Engramelle's treatise La tonotechnie should be understood: he claimed that his automated technology would enable composers to disseminate their music and its associated performance practices across time and geographical space with an ideal purity that would demonstrate its greatness. Working with the skilled artisan-musicians responsible for pinning the cylinders for use in automated instruments, the composers would ensure that the resulting cylinders would realize whatever was in their musical imaginations.

Engramelle's application of automated technology to music was related to broader tendencies in French thought and scientific cultures during the age of Enlightenment. A connection with materialist philosophy is suggested by a 1748 essay by Diderot that prefigured Engramelle's treatise in numerous ways. In this piece, Diderot outlined an aesthetic justification for automated musical instruments of the sort later expounded by Engramelle, in which he blurred the line between human musicians and musical machines. If this move seems strange today, it becomes clearer in light of the views of materialist philosophy, which saw both the human body and the human soul as functions of mechanics, understandable through analogy to machinery and android automata. ${ }^{8}$ Indeed, while such ideas had been in circulation in both popular and learned culture earlier in the eighteenth century, the classic statement on materialism, the treatise L'homme machine by Julien Offray de La Mettrie, appeared in print in the same year as Diderot's essay on automated musical instruments.

Consideration of Engramelle's automated technology from this perspective opens the door to an understanding of the performativity implicit in his treatise. In openly displaying a technology that had been kept a trade secret for centuries, Engramelle participated in the culture of popular science that dominated eighteenth-century France. La tonotechnie not only revealed a means for recreating the ideal performance of a given piece of music, but also unmasked the mysteries surrounding popular automata in human or animal form, such as those famously displayed by Jacques

7 Further on this topic, see David Chung, 'Revisiting Le bon goût: Observations on the Irregularities and Inconsistencies in French Harpsichord Music 1650-1730', Music and Letters, 92 (2011), 183-201.

8 On Descartes's ideas about the connections between automata and the human body as machine, see Alain Vizier, 'Descartes et les automates', Modern Language Notes, 111 (1996), 688-708; Thierry Gontier, 'Le corps humain est-il une machine? Automatisme cartésien et biopouvoir', Revue philosophique de la France et de l'étranger, 191 (2003), 27-53; and David Bates, 'Cartesian Robotics', Representations, 124 (autumn 2013), 43-68. 
Vaucanson in 1738. Such revelations were an integral part of the acquisition and spread of knowledge among educated listeners and spectators in the eighteenth century. If Engramelle's technology could be enacted only by a small number of artisans, his claim that his technology would preserve great works of French musical history for posterity gave all French listeners a stake in its success.

Engramelle's project culminated in his collaboration with the composer Claude Balbastre, one of the last leading figures of the French school of clavecinistes. Together, the composer and the artisan produced a notage - a notated map for the creation of a pinned cylinder - of a Romance by Balbastre, publishing it within François Bedos de Celles's treatise on organ building, L'art du facteur d'orgues, a volume considerably more dense and technical than La tonotechnie. ${ }^{9}$ Engramelle boasted that this notage represented a crystallization of Balbastre's playing style, thus fulfilling the purpose of the technology: to preserve the human art of musical performance through mechanization. Yet the notage raises as many questions as it answers. Even as Engramelle claimed fidelity to the composer, he made subtle but significant alterations to the articulations in Balbastre's work and, therefore, to the work's performance style. Even in applying a technology designed to preserve a single, idealized performance of the piece, the subjectivity of musical mediation stubbornly persisted.

\section{The musician as machine}

An understanding of Engramelle's effort to capture the vicissitudes of performance through La tonotechnie must begin from two related - yet sometimes conflicting aspects of French musical culture. The first of these is the difficulty, remarked upon by numerous French writers on performance, of capturing in notation the temporal flexibility inherent in French performance style. These writers claimed that foreign players, unable to discern this flexibility in notated music, judged French music inferior to their own. And, perhaps more significantly, even those players trained in France had lost the tradition of performance of earlier French masters such as Lully and Rameau. In other words, standard musical notation did not do justice to French music. The second aspect of French culture that provides context for Engramelle's project is the handful of attempts throughout the long eighteenth century - widely publicized in print - to create mechanical timekeeping devices for use in measuring time for the purpose of regulating musical performance. On the one hand, such mechanical timekeepers could preserve the basic tempos of compositions, thus conveying one important aspect of French practice. On the other, these devices could not accommodate the moment-by-moment flexibility that was claimed as an essential aspect of the French style. As I will show, pinned-cylinder technology was conceived as a synthesis - even an apotheosis - of these competing concerns.

${ }^{9}$ François Bedos de Celles, L'art du facteur d'orgues ([Paris], 1778); see Part 4, pp. 563-634. 
Writers and composers of the eighteenth century remarked frequently on the distinction between their national style and the styles of composers of other nations a circumstance that led, as is well known, to long-lived and continent-wide spats over the supremacy of one national style or another. It was perhaps the initiation of discussions about the merits of one national style over another, and a resulting selfconsciousness about how markers of national styles were conveyed in notation, that led numerous French writers to claim that foreign players could never hope to play French music well, for notation could not capture the flexible timing required for the execution of French music. A classic statement on this issue comes from Couperin's 1717 treatise L'art de toucher le clavecin, in which the composer called attention to the distinction between mesure (tempo) and cadence or mouvement (the flexible manner of execution of each beat). While not every writer of the eighteenth century observed this terminological distinction as clearly as Couperin did, many of them did write of similar phenomena in other terms. As Couperin explained:

I find that we confuse mesure with what one calls cadence or mouvement. Mesure is defined as the quantity and duration of time-beats, and cadence is, properly, the spirit and the soul that must be added to it. The sonatas of the Italians are hardly susceptible to this cadence. But our violin works, our compositions for harpsichord, for viols, etc. are designed and seem to want to express some sentiment. ${ }^{10}$

Susan McClary, among others, has observed the effects of this particularly French approach to conceptions of time in music in creating a sense of suspended time; she describes mouvement as the music's 'particular way of inhabiting each successive beat' ${ }^{11}$

The determination of the mouvement of a given passage of music was not simply a matter of personal preference. Le bon gồt could be subjective, to be sure, but determination of mouvement in music required attention to the details of the notation and its correct realization according to the intentions of the composer; in this understanding, there was indeed a 'correct' way of playing, and it was the player's responsibility to discern it. With some frustration Couperin explained the difficulties that performers had in deciphering the mouvement of French music. Addressing the

10 'Je trouve que nous confondons la mesure avec ce qu'on nomme cadence, ou mouvement. Mesure, dèfinit la quantité, et l'ègalité des tems: et cadence, est proprement l'ésprit, et l'âme qu'il y faut joindre. Les sonades des Italiens ne sont point susceptibles de cette cadence. Mais, tous nos airs de violons, nos pièces de clavecin, de violes, \&c. dèsignent, et semblent vouloir exprimer quelque sentiment.' François Couperin, L'art de toucher le clavecin (Paris, 1717), 40-1. A similar conception of mouvement is articulated by Johann Mattheson; see Christopher F. Hasty, Meter as Rhythm (New York and Oxford, 1997), Chapter 2: 'Two Eighteenth-Century Views' (pp. 22-33).

11 Susan McClary, 'Temporality and Ideology: Qualities of Motion in Seventeenth-Century French Music', Structures of Feeling in Seventeenth-Century Cultural Expression, ed. McClary (Toronto, 2013), 315-37 (p. 322). 
issue of notes inégales, the convention of playing successive notes written in equal values with more or less unevenness, Couperin wrote:

In my view there are defects in our style of writing music which correspond to the manner of writing our language. That is, we write differently from the way we perform; this is what makes foreigners play our music less well than we play theirs. By contrast, the Italians write their music in the true values that they intended. [...] Our usage has enslaved us, so we continue with it. ${ }^{12}$

Concerns about the transmission of music through notation likewise informed a project undertaken by Étienne Loulié and expounded in his Éléments ou principes de la musique of 1698. The project was his chronomêtre - a timekeeping device designed for use in music, consisting of a large pole with a pendulum hanging from its top. The length of the pendulum could be adjusted so that, when set into motion, its oscillations would occur either more or less quickly. By marking the length of the pendulum at the top of a piece of music, a composer could communicate a fixed tempo to anyone who wished to play the piece - that is, as long as the player also had a chronomêtre, enabling him or her to translate the composer's instruction into the tempo of the pendulum swing. Foreshadowing Couperin, Loulié wrote that his invention would be especially useful for conveying the true tempo of a piece of music to players in different regions or countries: 'Often musicians - even very experienced ones - cannot discover the true tempo of a piece, particularly with regard to the music of foreigners.' ${ }^{13}$ Perhaps more important, though, was Louliés concern with capturing the precise performance practices of the most famous French composer of the seventeenth century, Lully. As he explained,

I flatter myself that those who have fine taste, and who have seen how much of the beauty of a composition is lost if it is executed too quickly or too slowly, will appreciate my giving them a sure means of knowing the true tempo [of a work] - especially those who live in

12 'Il y à selon moy dans notre facon d'ecrire la musique, des déffauts qui se raportent a la manière d'écrire notre langue. C'est que nous écrivons diffèremment de ce que nous excécutons: ce qui fait que les ètrangers joüent notre musique moins bien que nous ne fesons la leur. Au contraire les Italiens ècrivent leur musique dans les vrayes valeurs qu'ils l'ont pensée. [...] Notre usage nous à asservis; et nous continüons.' Couperin, L'art de toucher le clavecin, 39-40. Jean-Jacques Rousseau used similar language about the habits of usage in presenting and advocating an entirely new system of musical notation, based solely on numbers rather than on musical staves and standard note symbols. Accusing musicians of viewing their art not as a 'science of sounds' but as one of 'blacks, whites, and doublecrochets', he lamented the 'habit' that allowed them to continue using an imperfect system of notation. See Rousseau, Dissertation, iv.

13 'Souvent des musiciens, mesme tres-habiles, ne conviennent pas sur le veritable mouvement d'une piece, particulierement à l'égard des musiques des etrangers.' Étienne Loulié, Éléments ou principes de musique: Mis dans un nouvel ordre trés-clair, trés-facile, \& trés-court \& divisez en trois parties (Amsterdam, 1698), 97; see also p. 100. 
the provinces, who can now know exactly the true tempo of all the works of Monsieur de Lully, which I have marked very exactly by means of the chronometre by consulting people who played them under the direction of Monsieur de Lully himself over the course of many years. ${ }^{14}$

Louliés instrument thus not only provided a means for executing the works of this great composer in their true 'tempo', but also served to record and spread the performance practices of the master, both to musicians residing outside Paris and to those in subsequent generations. Complicating the notion of the inseparable composerperformer, Loulié and his contemporaries were already anticipating the later panEuropean movement to perform the music of composers from the past. Thus while composers of the French Baroque often also performed, performers were not always composers, and keyboardists in remote locations could not be trusted to preserve information about performance practices in musical centres such as Paris, nor to know how to interpret notated music from past generations. In creating a mechanism to establish an absolute tempo, Loulié was filling a pedagogical need for these provincial performers, to be sure; but he was also removing some of the decision-making from the domain of the performer. He presented his chronomêtre as a device for ensuring the correct dissemination of musical information, and, as the inventor of the chronomêtre, he set himself up as the source of knowledge about Lully's performance style.

It seems clear that Loulié meant his chronomêtre to serve primarily as a general guide, rather than a device that should govern the moment-by-moment execution of a given piece of music; this is how Johann Joachim Quantz understood it when he related it to his own reference system for relative tempos - a system that relied on the 'pulse-beat at the hand of a healthy person'. ${ }^{15}$ Yet other French theorists of the eighteenth century tried to improve upon Louliés device by making it audible over the sound of the music, and thus applicable as a consistent, unwavering guide to the performance of a given work - much like the metronome of the nineteenth century. A player using Louliés method could not apply his device without looking at it to determine the apex of each swing of the pendulum, and it was therefore impractical for consistent use during the act of playing. By contrast, the so-called métromêtre invented by Louis-Léon Pajot, Comte d'Onzembray, and presented at the Académie Royale des Sciences in 1732, made a clicking sound with each swing of the pendulum, thus allowing the player to

14 'Je me flatte que ceux qui ont le goust fin \& qui ont éprouvé combien un air perd de sa beauté lorsqu'il est executé trop viste ou trop lentement, me sçauront bon gré de leur donner un moyen seur pour en connoître le veritable mouvement, particulierement ceux qui demeurent dans les Provinces, lesquels pouront sçavoir au juste le veritable mouvement de tous les ouvrages de Monsieur de Lully, que j'ay marqué tres-exactement par rapport au chronometre, avec le secours des personnes qui les ont executez sous la mesure de Monsieur de Lully mesme, pendant plusieurs années.' Ibid., 103.

15 Johann Joachim Quantz, Versuch einer Anweisung die Flöte traversiere zu spielen, trans. Edward R. Reilly as On Playing the Flute, 2nd edn (Boston, MA, 2001), 283-7. See also Alexander Evan Bonus, 'The Metronomic Performance Practice: A History of Rhythm, Metronomes, and the Mechanization of Musicality' (Ph.D. dissertation, Case Western Reserve University, 2010), 45-9 and 83. 
hear the beat precisely, even over the sound of the instrument. The métromêtre was designed to govern the tactus of a piece of music from beginning to end.

D'Onzembray was even more explicit than Loulié about the advantages of his métromêtre in preserving 'for posterity' the performance practices of composers:

There is no doubt that each composer has always been careful to have his pieces played more or less quickly, according to his taste; but he was never able to transmit [the tempo] for posterity, never having imagined a machine with which one could record the exact duration of bars and of pieces of music. This can be done easily by means of the vibration of a pendulum, because, as one can augment or diminish the duration of each vibration [of the pendulum] by lengthening or shortening the pendulum, one may know which length to give it. [...] Therefore all musicians can know the duration of bars and the tempo of pieces; they will never again be altered, and will be preserved for the future. ${ }^{16}$

'Never again be altered': this phrase confirms d'Onzembray's desire to stop the loss of knowledge of musical information through the years and generations. Like Loulié, d'Onzembray set himself up as the innovator who could make this wish a reality. Even in compounding the technology for the mediation and regulation of music, d'Onzembray claimed that the purpose of his technology was the pursuit of a musical truth.

Despite its advantages for the transmission of knowledge about tempo from one generation to the next, d'Onzembray's invention was at odds with the principle that Couperin called mouvement or cadence - the temporal flexibility from one moment to the next that constituted such an important point of pride for French writers and performers. Thus, when Diderot reported in 1748 his own view of tools like the chronometre and the métromêtre, he admitted that 'the only good chronometer is an experienced, tasteful musician, who has read the score carefully, and who knows how to keep time'. ${ }^{17}$

16 'Il est cependant hors de doute que chaque compositeur a toûjours eu grande attention à faire executer sa musique plus ou moins vivement, suivant le goût qu’il a eu; mais il n’a pû le transmettre à la postérité, n'ayant pas imaginé une machine avec laquelle on pût constater la juste durée des mesures \& des temps des airs de musique. C'est ce qu'on peut faire aisément par les vibrations du pendule; car comme on peut augmenter ou diminuer la durée de chaque vibration en allongeant ou raccourcissant le pendule, on peut connoître quelle longueur il faut lui donner. [...] Alors tous les musiciens connoîtront la durée des mesures \& des temps des airs, elles ne seront plus altérées, \& se conserveront à l'avenir.' Louis-Léon Pajot, Comte d'Onzembray, 'Description et usage d'un métrometre, ou machine pour battre les mesures \& les temps de toutes sortes d'airs', Histoire de l'Académie Royale des Sciences, Année 1732 (Paris, 1735), 182-95 (p. 182; emphasis added). On the relationship between d'Onzembray's invention and that of Loulié, see Albert Cohen, 'French Time Devices Revisited', Dutch Journal of Music Theory, 15 (2010), 169-89, and Cohen, Music in the French Royal Academy of Sciences: A Study in the Evolution of Musical Thought (Princeton, NJ, 2014), 68-9.

17 'Le seul bon chronométre que l'on puisse avoir, c'est un habile musicien qui ait du goût, qui ait bien lû la musique qu'il doit faire exécuter, \& qui sache en battre la mesure.' Denis Diderot, Mémoires sur différens sujets de mathématiques (Paris, 1748), 194. 
If, in this statement, Diderot seems to have expressed faith in the abilities of musicians, the overall context in which he made this observation - characteristically penetrating and sarcastic - contradicts such an impression. ${ }^{18}$ The passage in question comes from the fourth essay in Diderot's Mémoires sur différens sujets de mathématiques of 1748 , in which he discussed two different mechanical inventions for measuring time in music. The first part of the essay, a version of which had been published anonymously in the Mercure de France in the preceding year, discussed Diderot's 'plan for a new organ on which one can play every piece of music for two, three, four parts, etc.; [it is an] instrument equally useful for those who know enough about music to compose, and for those who know nothing at all'. ${ }^{19}$ The essay describes - albeit in vague terms - the technology of pinning cylinders to produce music precisely as intended by its composer, prefiguring Engramelle's treatise of more than a quarter of a century later. Confessing that his investigation of this topic began as 'half-serious, half in jest', ${ }^{20}$ stemming from the fact that he 'like[d] music very much, and [...] would like to know a great deal about it without having to learn anything, ${ }^{21}$ Diderot claimed to have developed a means for any piece to be played on a mechanical organ in the manner intended by its composer, rather than leaving the execution of music to poor performers. Indeed, he spared no insult for professional musicians, writing that

one would certainly take greater pleasure in hearing this instrument than a mediocre organist (which the majority of them are) who knows nothing but how to stutter on his organ, never proceeds in time, plays discords at every instant, repeats himself without end, and never repeats anything unless it is bad. ${ }^{22}$

He continued by noting wryly that many a provincial gentleman, driven from church by incompetent organists, would be brought back by an instrument such as his.

18 The brief assessment of Diderot's description of the chronomêtre offered by Roger Matthew Grant seems not to take this larger context into account; see Grant, Beating Time and Measuring Music in the Early Modern Era (Oxford, 2014), 133.

19 'Projet d'un nouvel orgue sur lequel on pourra exécuter toute piece de musique à deux, trois, quatre, \&c. parties, instrument également à l'usage de ceux qui sçavent assez de musique pour composer, \& de ceux qui n'en sçavent point du tout'. Diderot, Mémoires, 169. See also Diderot's essay, published anonymously, 'Projet d'un nouvel orgue sur lequel on pourra exécuter toute pièce de musique à deux, trois, quatre, cinq parties \& davantage, instrument également à l'usage de ceux qui sçavent assés de musique pour composer, $\&$ de ceux qui n'en sçavent point du tout', Mercure de France (October 1747), 92-109.

20 'Moitié sérieuses, moitié folâtres'. Diderot, Mémoires, 173.

21 'J'aime beaucoup la musique, \& [...] je voudrais bien la sçavoir \& ne la point apprendre.' Ibid., 171. A survey of Diderot's approach to music is in Paul Henry Lang, 'Diderot as Musician', Diderot Studies, 10 (1968), 95-107.

22 'On auroit certainement plus de plaisir à entendre cet instrument qu'un organiste médiocre, comme la plûpart le sont, qui ne sait que balbutier sur son orgue, ne marche jamais en mesure, pratique à chaque instant des accords déplacés, se répéte sans fin, \& ne répéte jamais que de mauvaises choses.' Diderot, Mémoires, 185-6. 
The aesthetic implications of Diderot's proposal for a mechanical organ emerge in the second section of the essay - a section that had not appeared in the Mercure de France previously. This portion of the essay took as its subject the chronomêtre (Diderot subsumed under this term the inventions of Loulié and of d'Onzembray, as well as others like theirs), ${ }^{23}$ and it was in this context that Diderot admitted that the temporal flexibility so essential to the French style of playing music could not be subjected to the strictness of the timekeeping instruments developed by Loulié and his followers. Instead, Diderot proposed that a pendulum-based instrument like the chronomêtre be 'applied' to a mechanical organ operated by means of a pinned cylinder. In this way, the piece would always be executed at the correct tempo, for its total duration would be measured precisely, in seconds, rather than using relative terms such as vite or lent; however, the mouvement of individual passages as intended by the composer - the fluctuations and irregularities in the placement of each note, which depend on the harmonic, melodic and textural context - would be preserved.

Diderot did not sully his hands with the precise details of how the chronometric pendulum would be 'applied' to the mechanical organ, writing: 'I will not enter at all into the manner in which this application of the pendulum to the cylinder can be done; it is a good clockmaker who should be consulted on that matter. ${ }^{24}$ Nevertheless, his conception of the relationship between the pinned cylinder on the one hand and the chronometre on the other is significant for the light that it sheds on conceptions of human creativity and expression in automated music. He cast both the human performer and the chronomêtre as machines:

One has made of the musician and the chronometer two distinct machines, of which the one can never be accommodated to the other. This hardly needs to be demonstrated: it is not possible for the musician to have his eye on the motions or his ear on the sound of the pendulum throughout his piece. [...] But how, one might ask me, can we make of the musician and the chronometer one and the same machine? It seems that this is impossible. ${ }^{25}$

Yet this, Diderot claimed, was precisely what the mechanical organ could achieve: the conflict between the subjectivity and fallibility of the human performer and the unrelenting nature of the chronometric instrument could be resolved by an automated musical machine, prepared by the artisan and the composer together. Composers

23 Much of the article 'Chronomêtre' in the Dictionnaire de musique of Rousseau was taken up with responding to this essay by Diderot. See Jean-Jacques Rousseau, Dictionnaire de musique (Paris, 1768), $98-100$.

24 'Je n'entrerai point dans la maniere dont cette application du pendule au cylindre peut se faire; c'est un bon horloger qu'il faut consulter là-dessus.' Diderot, Mémoires, 196.

25 'On y a fait du musicien $\&$ du chronométre deux machines distinctes, dont l'une ne peut jamais bien assujettir l'autre. Cela n'a presque pas besoin d'être démontré: il n'est pas possible que le musicien ait pendant toute sa piéce l'oeil au mouvement ou l'oreille au bruit du pendule. [...] Mais comment, me demandera-t-on, faire du musicien $\&$ du chronométre une seule $\&$ même machine. Il paroît que cela est impossible.' Ibid., 195 (emphasis added). 
ought to be willing to abandon their subjective musical notation, writing instead at the head of each piece precisely how many seconds the piece was meant to last. A pendulum could then be used to govern the pinned-cylinder organ; the total allotted time would be divided by the number of bars that needed to be played. The result would be a performance of the piece with precisely the right tempo, played with the ease and flexibility recorded by the composer in the pinned cylinder.

Thus Diderot took it upon himself to resolve the conflict between the regular beat of the chronometre and the temporal flexibility of French music: composer-performers would record their music on cylinders, preserving their individual performing styles and compositional intentions, including the precise placement of each note and the mouvement of the work as a whole, while the tempo - the large-scale mesure that determines the character of the work - would be governed by the pendulum. Bypassing the technological difficulties involved, Diderot chose instead to focus on the aesthetic results of the juxtaposition of the musician and the chronomêtre - 'deux machines distinctes'.

As Diderot's essay makes clear, the application of automatic machinery - both the cylinder organ and the chronomêtre - to the art of music had the capacity to augment its emotional impact through the preservation of the precise performance style and mouvement of the composer. Far from rendering music faceless or impersonal, the synthesis of the human composer-performer with the machinery of the mechanical organ would allow a more faithful, and thus more expressive, performance. ${ }^{26}$

\section{Artisanship and public display}

The basic technology that Engramelle described had its roots in a long tradition of the use of cylinders as the driving mechanisms for automated musical instruments and other automata. ${ }^{27}$ The foundation for his work was laid in the Renaissance, when humanist scholars and the artisans in their employment, inspired by accounts of such ancient Greek inventors as Hero of Alexandria, had attempted to simulate the motions of life through the invention of automated machinery. ${ }^{28}$ While some

26 Among the recent studies that have called into question the widespread assumption that mechanical music cannot be expressive is Annette Richards, 'Mozart and the Mechanical Sublime', Music and Letters, 80 (1999), 366-89, which proposes that Mozart's music for mechanical organ is both idiomatic and capable of being played uniquely on a non-human-operated instrument, and therefore inspires the listener's sense of wonder at the sublime.

27 Teun Koetsier has identified a possible usage of pinned cylinders for the operation of automated machinery as early as the thirteenth century, but certainly by the 1500s; see Koetsier, 'On the Prehistory of Programmable Machines: Musical Automata, Looms, Calculators', Mechanism and Machine Theory, 36 (2001), 589-603.

28 See Horst Bredekamp, The Lure of Antiquity and the Cult of the Machine: The Kunstkammer and the Evolution of Nature, Art, and Technology, trans. Allison Brown (Princeton, NJ, 1995), 46-51 and 
of these Renaissance-era inventions were illustrated in books known as 'theatres of instruments', such volumes generally contained only short descriptions of the technology that powered the automata; details of the machinery were often kept secret with a view to inspiring the wonder and curiosity of the reader.

Engramelle's treatise departed from this tradition by expounding on the technology at length, putting in print what would earlier have been thought of as a trade secret. In publicizing his technology - in unveiling the mechanism that had driven cylinder technology in more or less the same way for centuries - Engramelle joined numerous other inventors, curators and merchants of the eighteenth century who cultivated a public 'spectacle of science'. ${ }^{29}$ Within this environment, inventors and natural philosophers sought to reveal the workings of the natural and man-made worlds to an eager public, hungry for easily digestible knowledge.

The frontispiece of La tonotechnie (see Figure 1) highlights the place of his treatise within this broader culture of public science. The engraving, as Engramelle explained,

places before the eyes of the reader the most sought-after operations of La tonotechnie [...]: at the side is a cylinder-harpsichord; behind it is an automaton playing the flute, its pedestal left open to show the mechanism that drives it; at the bottom is seen a cylinder-organ, and in the light of the window a chiming clock with a pendulum. ${ }^{30}$

(In case there should be any doubt about the realism of this and other images in the book, Engramelle assured his reader that 'for greater precision, the author has made all of the drawings and engravings himself' ${ }^{31}$ ) Engramelle's readers might well have recognized the flute-playing automaton pictured here as an approximation of the famous automaton flute-player crafted by Vaucanson and displayed - together with an automaton that played a pipe and tabor and another in the form of a duck that could eat, digest and expel waste - in Paris in 1738 (see Figure 2).

passim. See also Silvio Bedini, 'The Role of Automata in the History of Technology', Technology and Culture, 5 (1964), 24-42; Jonathan Sawday, "Forms Such as Never Were in Nature": The Renaissance Cyborg', At the Borders of the Human: Beasts, Bodies, and Natural Philosophy in the Early Modern Period, ed. Erica Fudge, Ruth Gilbert and Susan Wiseman (New York, 1999), 171-95; and Sawday, Engines of the Imagination: Renaissance Culture and the Rise of the Machine (New York, 2007). On musical automata around the turn of the seventeenth century and their relationship to the instrumental music of the period, see Rebecca Cypess, Curious and Modern Inventions: Instrumental Music as Discovery in Galileo's Italy (Chicago, IL, 2016), 26-9 and 152-5.

29 See Science and Spectacle in the European Enlightenment, ed. Bernadette Bensaude-Vincent and Christine Blondel (Aldershot, 2008).

30 'Met sous les yeux du lecteur les opérations les plus recherchées de la Tonotechnie [...] à côté est un clavessin à cylindre; derrière cet instrument paroît un automate jouant de la flûte, son piédestal ouvert laisse entrevoir le méchanisme qui le conduit: dans le fond se voit un orgue à cylindre, \& dans l'embrâsement de la croisée une pendule à carrillon'. Engramelle, La tonotechnie, 'Avis aux relieurs' (unpaginated).

31 'L'auteur a fait lui-même tous les dessins \& les gravures, pour plus de précision.' Ibid. 


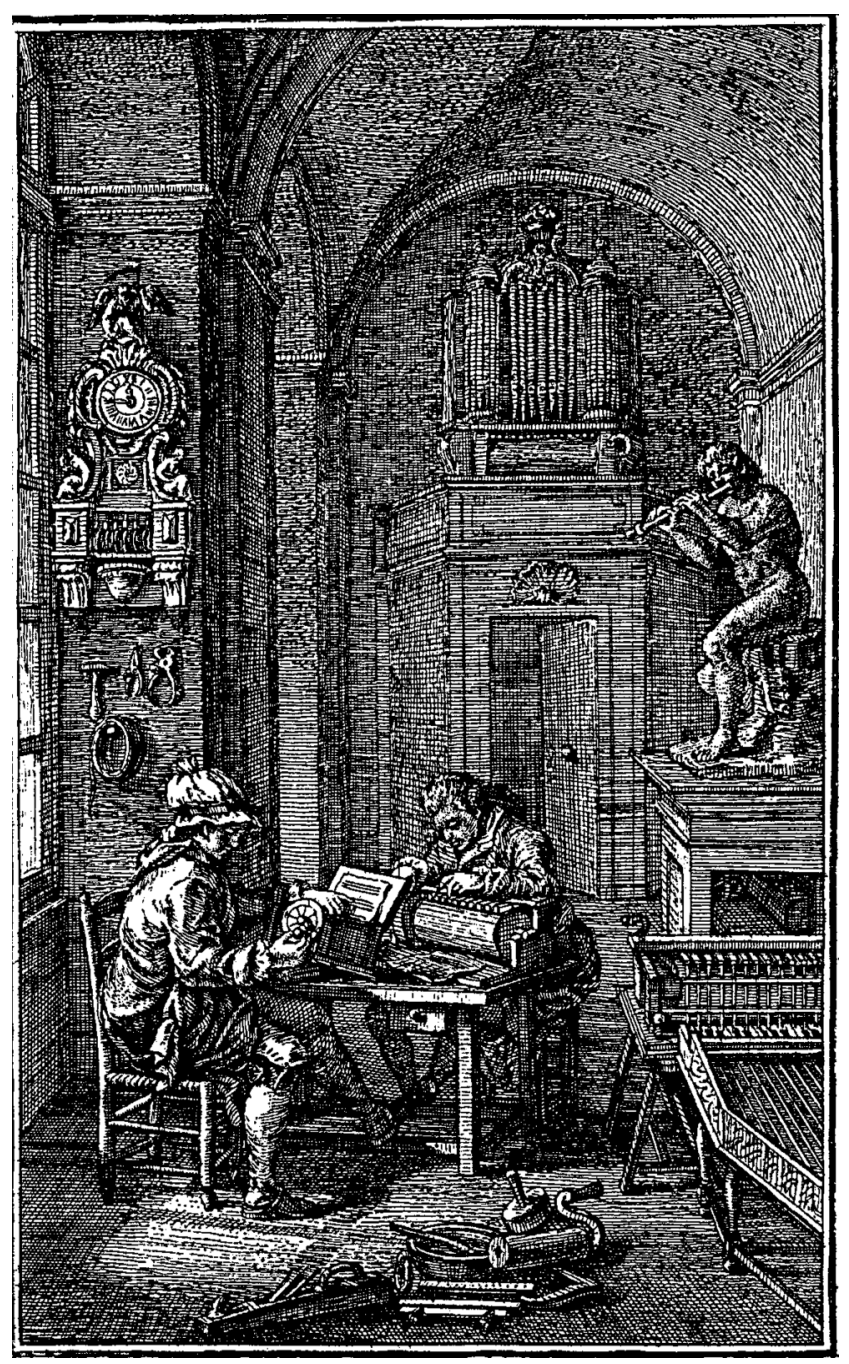

Figure 1. Frontispiece, Marie-Dominique-Joseph Engramelle, La tonotechnie, ou l'art de noter les cylindres (Paris, 1775).

The relationship between Vaucanson's automata and Engramelle's treatise is noteworthy, for, as Engramelle explained, Vaucanson's creations relied on the very technology that Engramelle unveiled in La tonotechnie. In this context, it is significant that two of Vaucanson's three automata relied on music as a marker of their verisimilitude. Indeed, Vaucanson's creation of the flute-player involved technological feats that stretched the boundaries of both human capability and mechanical technology. The automaton could actually play any flute placed in its hands - an accomplishment difficult enough for human players, since the instrument presented innumerable difficulties, resulting from the variations that it required in 


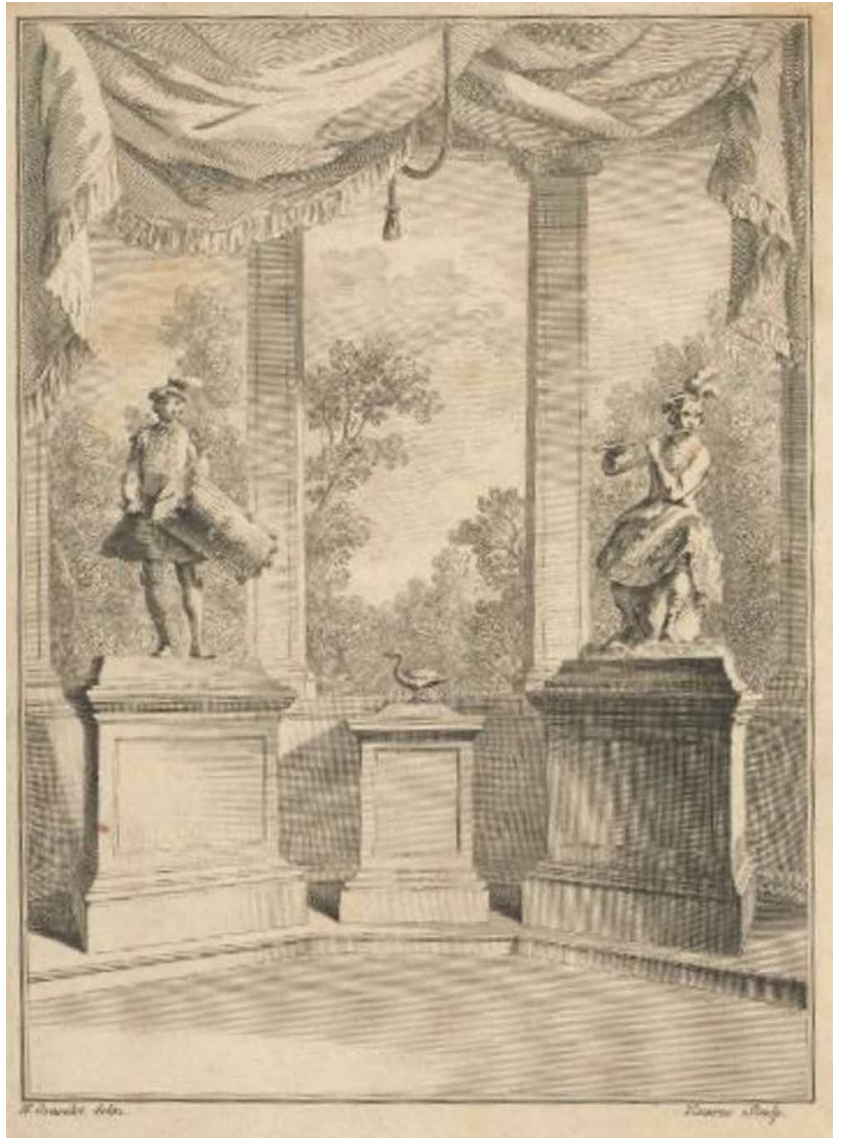

Figure 2. Jacques Vaucanson's three automata: the flute-player, the duck and the pipe-and-tabor player. From Vaucanson, An Account of the Mechanism of an Automaton, or, Image Playing on the German-flute: As was Presented in a Memoire to the Gentlemen of the Royal-Academy of Sciences at Paris (London, 1742). Harvard University, Houghton Library, Hyde Mus. 359.10.

breath control, embouchure and articulation. In the pamphlet entitled Le mécanisme du futeur automate that he submitted to the Académie Royale des Sciences as evidence of his flute-player's authenticity and ingenuity, ${ }^{32}$ Vaucanson stressed that the construction of this flute-player required a careful knowledge of the physical process of playing the flute. Whereas seventeenth-century automata might simulate the motions of a musician but produce sound through some unconnected mechanism, Vaucanson's flute-player actually played his instrument - breathing into it, fingering its holes with automatic finger movements, and adjusting the air pressure and angle of the instrument to alter the pitch further. It was apparently in response to viewers'

32 Jacques Vaucanson, Le mécanisme du fluteur automate, présenté à Messieurs de l'Académie Royale des Sciences (Paris, 1738). 
initial disbelief that the flute-player was really playing his instrument that Vaucanson felt compelled to explain its workings to the reading public. ${ }^{33}$ In his pamphlet he stressed the connection between his automaton and a human flute-player, claiming to demonstrate how these different motions have contributed to produce the effect which I have proposed in this automaton, comparing them with those of a living person'. ${ }^{34}$ Yet, as Jessica Riskin notes, 'he deliberately chose an instrument that involved motions he could only approximate', yet 'he was nevertheless able to use his simulation to discover features of its natural subject'. ${ }^{35}$ Members of the Académie Royale des Sciences were satisfied that Vaucanson's automaton truly performed its mechanical operations to play its flute, rather than merely creating the illusion of musical performance. In his description of its workings, appended to Vaucanson's published pamphlet on his automaton, the secretary of the academy confirmed that the members of his institution had

judg'd this machine to be extremely ingenious, and that the author of it has found the means of employing new and simple contrivances, as well for giving the fingers of that figure the necessary motions, as for modifying the wind which goes into the flute by encreasing or diminishing its velocity, according to the different notes; by varying the position of the lips, and moving a valve which performs the office of the tongue; and lastly, by imitating by art all that is necessary for a man to perform in such a case. ${ }^{36}$

The automaton flute-player thus compounded the artifice required for the playing of music. A human flautist is required to master all of the subtle and difficult aspects of performance on the instrument, adjusting air pressure, shape of the mouth, angle of the mouthpiece and so on according to the needs of the instrument and the music being played. Vaucanson studied these aspects of musical performance by means of an instrument and the human physiology and techniques needed to perform them, but he then conceived a mechanical means of imitating these human physiological

33 Alfred Chapuis and Edmond Droz, Automata: A Historical and Technological Study, trans. Alec Reid (Neuchâtel, 1958), 274; Jessica Riskin, 'The Defecating Duck, or, the Ambiguous Origins of Artificial Life', Critical Inquiry, 29 (2002-3), 599-633 (p. 615).

34 'Comment tous ces différens mouvemens ont servi à produire l'effet que je me suis proposé dans cet automate, en les comparant avec ceux d'une personne vivante'. Vaucanson, Le mécanisme du fluteur automate, 15, trans. in An Account of the Mechanism of an Automaton, or, Image Playing on the Germanflute: As was Presented in a Memoire to the Gentlemen of the Royal-Academy of Sciences at Paris (London, 1742), 16.

35 Riskin, 'The Defecating Duck', 616.

36 'Extrémement ingénieuse, que l'auteur avoit sçu employer des moyens simples \& nouveaux, tant pour donner aux doigts de cette figure, les mouvemens nécessaires, que pour modifier le vent qui entre dans la flute en augmentant ou diminuant sa vitesse, suivant les différens tons, en variant la disposition des lévres, \& faisant mouvoir une soûpape qui fait les fonctions de la langue; enfin, en imitant par art tout ce que l'homme est obligé de faire'. Vaucanson, Le mécanisme du fluteur automate, supplement by Fontenelle, perpetual secretary of the Académie Royale des Sciences, 20, trans. in An Account of the Mechanism of an Automaton, 20-1. 


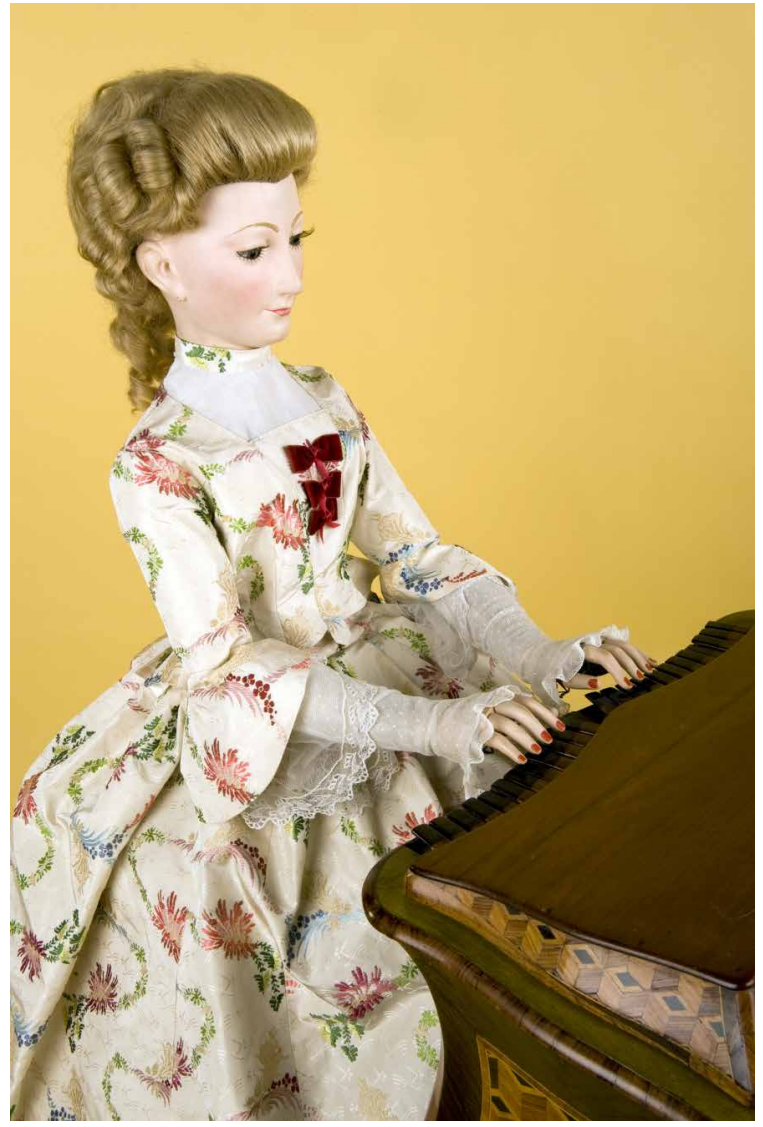

Figure 3. Pierre and Henri-Louis Jacquet-Droz, 'The Keyboard Player'. Musée d'Art et d'Histoire de Neuchâtel, Inventory AA 1. Reproduced by permission of the Musée d'Art et d'Histoire de Neuchâtel.

processes. Through his ingenuity, he became a master of both nature and art, and it was in this doubling of the artifice involved in musical performance that he inspired the admiration of both the intelligentsia of the Académie Royale des Sciences and the public at large. ${ }^{37}$

That the imitation of human expression formed an essential component of the most celebrated automata of the eighteenth century is clear from descriptions of the automaton keyboard-player built between about 1772 and 1774 by the clockmakers Pierre and Henri-Louis Jacquet-Droz. This keyboard-player (see Figure 3) is an

37 On automata that were produced not for public display but for patrons of noble birth, see Adelheid Voskuhl, Androids in the Enlightenment: Mechanics, Artisans, and Cultures of the Self (Chicago, IL, 2013), 86-127, as well as the account of Vaucanson's attempt to create a mechanical circulatory system in Max Byrd, 'Man as Machine', Wilson Quarterly, 36/1 (winter 2012), 30-4. See also Paul Metzner, Crescendo of the Virtuoso: Spectacle, Skill, and Self-Promotion in Paris during the Age of Revolution (Berkeley, CA, 1998), 167-73. 
automaton in the form of a young woman, approximately four feet high, elaborately dressed and made up, with even her fingernails polished. She is seated on a bench, and inside the bench is a pinned-cylinder mechanism - a product of the JacquetDroz family's expertise in clockwork - that causes her to move. Like Vaucanson's flute-player, the Jacquet-Droz keyboard-player actually plays her instrument, though it needs to be modified with a split keyboard so that her fingers can reach all the keys necessary. (Originally, she had before her a combination harpsichord-organ, but this has since been replaced by a small organ. ${ }^{38}$ ) Her hands, which, as Riskin notes, display an internal construction very much like the bone structure of a human hand, operate the keys in front of her.

But the aspects of her performance that made her most lifelike - and therefore most impressive to the spectators who paid to view her - were the movements of her body, for these gave the impression that this petite automaton was actually expressive. This feature of her performance was described in the pamphlets that the Jacquet-Droz workshop distributed; as the English version of this pamphlet explained:

The first figure represents a girl of ten or twelve years of age, sitting on a stool and playing on a harpsichord. This automaton, whose body, head, eyes, arms, hands and fingers have various motions, all which appear natural, performs several airs in two or three parts with great precision; the head has every natural motion, and the eyes look indiscriminately on its hands, the music and the spectators; the body is flexible, and inclines sometimes to see the music nearer; the bosom also rises and falls, to imitate respiration. ${ }^{39}$

Adelheid Voskuhl has emphasized the significance of these lifelike bodily motions, arguing that they functioned as markers of the bourgeois culture of sentimentalism that became widespread in Europe in the second half of the eighteenth century. Within eighteenth-century musical culture, expression of sentiment often went hand in hand with physical movement and gesture, and the fact that these overlap within the JacquetDroz keyboard-player enhances both its spectacle and its ability to arouse a sentimental reaction within the audience. ${ }^{40}$ The pamphlet's lengthy remarks about the automaton's

38 Voskuhl, Androids in the Enlightenment, 130. This automaton has been restored, and numerous videos of it are available online; see, for example, <www.youtube.com/watch?v=IeTOqDb-86s > (accessed 11 December 2016).

39 Henri-Louis Jacquet-Droz, A Description of Several Pieces of Mechanism, Invented by the Sieur Jacquet Droz, of [...] Switzerland. And which are now to be seen at the Great Room, no. 6, in King-Street, CoventGarden (London, 1780).

40 See Voskuhl, Androids in the Enlightenment, 128-9, 142-5, 162-9 and passim. Interestingly, Couperin did not advocate bodily movement during performance, writing: 'It is better and more becoming not to mark the tempo with the head, the body or the feet. One should have an easy air at the harpsichord, without having the gaze fixed on any one object, nor having an overly vague air, but rather looking at the company in which one finds oneself, as if one were not occupied otherwise' ('Il est mieux, et plus séant de ne point marquer la mesure de la teste, du corps, n’y des pieds. Il faut avoir un air aisé a son clavecin: sans fixer trop la vüe sur quelque objet, ny l'avoir trop vague: enfin regarder la compagnie, 
concomitant musical performance and expressive physical motions underscore the role of such technological marvels as vehicles for shared, public experiences of sentiment. ${ }^{41}$

Little wonder, then, that Engramelle should construct La tonotechnie upon the scaffolding of well-known automata such as Vaucanson's flute-player. In placing an image of people applying his pinned-cylinder technology to a keyboard instrument alongside an image of the famous flute-player, its pedestal open to the curious gaze of the reader, Engramelle asserted his own place at the intersection of technology, sentiment, public spectacle and shared cultural experience. Indeed, it was perhaps this sense of shared experience that prompted Engramelle - and Loulié, d'Onzembray, Diderot and others before him - to emphasize the role of his technology in constructing and preserving a French musical tradition. As these justifications imply, the technology was essential above all because it would allow listeners distant in place and time to partake of a common - and uncommonly worthwhile - social, intellectual and artistic heritage.

If the juxtaposition of automation and human expression, whether in the JacquetDroz keyboard-player or in Engramelle's pinned cylinders, seems incongruous today, this connection lay at the heart of the materialist philosophy of the eighteenth century. Indeed, popular cultural artefacts such as Vaucanson's automata made their way into the writings of some of the most revolutionary French thinkers of the age, who saw automata as a means of experimentation that would lead to new understandings of human life. ${ }^{42}$ To build an automaton was to proceed, step by step, through the process of creation. Indeed, Vaucanson himself was cast as a Promethean figure in La Mettrie's L'homme machine (1748), which argues that 'the human body is a machine which winds itself up, a living picture of perpetual movement' ${ }^{43}$ Rejecting the dichotomy between body and soul that lay at the heart of Cartesian dualism, La Mettrie and

s'il s'en trouve, comme sy on n'étoit point occupé d'ailleurs'). By mid-century this advice had become outdated, as confirmed in treatises of C. P. E. Bach, Quantz and others. See Couperin, L'art de toucher le clavecin, 5-6.

41 Further on the combination of sentiment and physical motion in these automata, see Lawrence Kramer, 'From Clockwork to Pulsation: Music and Artificial Life in the Eighteenth Century', Experimental Affinities in Music, ed. Paolo de Assis (Leuven, 2016), 147-67 (pp. 156-9). On the implications of these expressive machines for the nascent orchestra, see Emily I. Dolan, The Orchestral Revolution: Haydn and the Technologies of Timbre (Cambridge, 2013), 203 and passim.

42 As Voskuhl has shown, it was not until the nineteenth century that more cautious, eerie characterizations of humanoid automata began to take hold. See Voskuhl, Androids in the Enlightenment, 124-7 and 201-25; and see also Minsoo Kang, Sublime Dreams of Living Machines: The Automaton in the European Imagination (Cambridge, MA, 2011), 185-222. E. T. A. Hoffmann's story 'The Sandman', published in his Nachtstücke of 1817, is a prime example from the post-Enlightenment concerning the boundaries between automata and human beings. See the discussion in Katherine Hirt, When Machines Play Chopin: Musical Spirit and Automation in Nineteenth-Century German Literature (Berlin, 2010), 33-64.

43 Julien Offray de La Mettrie, Machine Man and Other Writings, trans. Ann Thomson, Cambridge Texts in the History of Philosophy (Cambridge, 1996), 7. 'Le corps humain est une machine qui monte elle-même ses ressorts; vivante image du mouvement perpetuel.' La Mettrie, L'homme machine (Leiden, 1748), 14. 
other materialists claimed that the soul was essentially linked to the workings of the body: when the body flourishes, so does the soul; as the body declines, the soul grows weaker as well. ${ }^{44}$ It was on these grounds that La Mettrie and his followers asserted the usefulness of automata, mentioning Vaucanson by name and comparing him to Prometheus; in this world-view, automata served as a test case for the idea of mechanistic materialism. All life existed along a single continuum, with the principles of mechanics at its core:

We can see that there is only one substance in the universe and that man is the most perfect one. [...] If it took more instruments, more cogs, more springs to show the movement of the planets than to show or tell the time, if it took Vaucanson more artistry to make his flutist than his duck, he would have needed even more to make a speaking machine, which can no longer be considered impossible, particularly at the hands of a new Prometheus. ${ }^{45}$

Vaucanson's experiments with automated technology were playful machines, to be sure, but La Mettrie placed such play at the centre of his proof about the mechanical nature of both the human body and the soul. ${ }^{46}$ Vaucanson himself may first have become interested in creating automata when he was a medical student, since his studies exposed him to the idea that working physiological models could teach physicians about the nature of human life; this point underscores the relationship between popular and learned science. ${ }^{47}$ As Horst Bredekamp has shown, automata had long functioned in European society as a nexus of creative ingenuity and playful experimentation. ${ }^{48}$

Whereas Diderot, in the Mémoires, wrote disparagingly of curiosities such as android automata, ${ }^{49}$ Engramelle, like La Mettrie, instead placed automata front

44 The issue of human consciousness within this system presented a paradox for enlightened thinkers, since consciousness could not be ascribed to machinery in any straightforward way. Yet, as Aram Vartanian has shown, this difficulty allowed a thinker like Diderot to revel in the consideration of the apparent contradiction; see Vartanian, 'Diderot's Rhetoric of Paradox, or, The Conscious Automaton Observed', Eighteenth-Century Studies, 14 (1980-1), 379-405.

45 La Mettrie, Machine Man and Other Writings, trans. Thomson, 33-45. 'On voit qu'il n'y en a qu'une dans l'univers \& que l'homme est la plus parfaite. [...] S'il a fallu plus d'instruments, plus de roüages, plus de ressorts pour marquer les mouvemens des planètes, que pour marquer les heures, ou les repeter; s'il a fallu plus d'art à Vaucanson, pour faire son fluteur, que pour son canard, il eût dû en emploier encore davantage pour faire un parleur; machine qui ne peut plus être regardée comme impossible, surtout entre les mains d'un nouveau Prométhée.' La Mettrie, L'homme machine, 92-3.

46 On toys as sites of experimentation in the eighteenth century, see Liliane Pérez, 'Technology, Curiosity and Utility in France and in England in the Eighteenth Century', Science and Spectacle in the European Enlightenment, ed. Bensaude-Vincent and Blondel, 28-36.

47 Metzner, Crescendo of the Virtuoso, 166; see also Thomas L. Hankins and Robert J. Silverman, Instruments and the Imagination (Princeton, NJ, 1995), 182. On the broader philosophical context of automata, see Voskuhl, Androids in the Enlightenment, 22-4 and passim.

48 Bredekamp, The Lure of Antiquity, 69-80.

49 'If the famed Vaucanson [...], who has made a wooden duck eat and live, and [made] statues play the flute, were to propose this other machine I do not doubt but that he would soon master it, and 
and centre in La tonotechnie, alongside conventional musical instruments that could also be programmed using pinned cylinders. He lamented the fact that the art of pinning cylinders had been 'shrouded until now under the mysterious shadow of secrecy', and that 'this ignorance has deprived the public of an infinite number $[\ldots]$ of advantages'. ${ }^{50}$ Among these, to be sure, was the knowledge of the interior workings of automata. He claimed that the 'notage of automata or other extraordinary instruments does not require any more difficulty than that of a small barrel organ [serinette] ${ }^{51}$ and he mentioned specifically automata in the form of both keyboard-players and flute-players as examples of the combined automation of both physical motion and sound.

Yet chief among Engramelle's concerns - overriding curiosities such as android automata - was the loss of the knowledge of past performance practices owing to the imprecision of musical notation and the fleeting nature of musical performance. In expressing this concern he joined the numerous other French writers who, as discussed above, sought various means - including the use of mechanical timekeeping devices - to preserve and disseminate their national performance practices across geographical regions and through generations. Lamenting the bad musical habits and poor understanding of provincial keyboardists, who repeatedly subjected the music they played to the most insensitive realizations, Engramelle argued that use of his technology would restore French music of the past to its place of honour. Key to his understanding was the notion that the composer's intentions and manner of playing were the highest aesthetic ideal:

One may say that a well-made cylinder-driven machine would render musical works with a cleanness and a correctness in execution that even the best musician could not attain, because it would be without error, and because if these pieces were arranged on cylinders by their composers, they would transmit them to posterity in their purity; thus they would not run the risk of being disfigured after [their deaths...], for the Lullys, the Corellis, the Couperins and the Rameaus themselves would be revolted if they were to hear their pieces the way they are executed at present..$^{52}$

incessantly announce to us an automaton-organist. And why not? Would it be the first we've seen?' ('Si le célébre Vaucanson [...] qui a fait manger \& vivre un canard de bois, \& jouer de la flute à des statuës, se proposoit cette autre machine, je ne doute point qu'il n'en vint à bout, \& qu'on ne nous annonçât incessamment un organiste automate. Et pourquoi non? Seroit-ce le premier qu'on auroit vû?'). Diderot, Mémoires, 173.

50 'Enveloppée jusqu'ici sous l'ombre mystérieuse du secret'; 'cette ignorance a privé le public d'une infinité [...] [des] plus grands avantages'. Engramelle, La tonotechnie, i-ii.

51 'Le notage des automates ou des autres instrumens extraordinaires ne souffriroit pas plus de difficulté que celui d'une serinette.' Ibid., 169.

52 'On pourroit même dire qu'une machine à cylindre bien éxécutée, rendroit les piéces de musique avec une netteté $\&$ une justesse d'exécution à laquelle le meilleur musicien ne peut jamais atteindre, parce qu'elle seroit sans erreur, \& que si ces piéces étoient notées sur les cylindres par leurs auteurs, ils les transmettroient à la postérité dans leur purété; alors elles ne courroient pas les risques d'être défigurées après eux $[\ldots]$ ensorte que les Lulli, les Corelli, les Couprin \& les Rameau même seroient révoltés s'ils entendoient leurs morceaux tels qu'on les exécute à présent.' Ibid., 62-3 (emphasis added). 
Engramelle envisioned the involvement of the composer in the notage of pieces - a process that, as we shall see, he claimed to have brought to fruition in his collaboration with Balbastre - so that the composer's exact performance practices could be preserved. Indeed, his frontispiece (see again Figure 1) seems to show two men of different rank working together with Engramelle's technology, and it is possible that they represent the artisan and the composer. Replication of the composer's playing style was so essential that Engramelle actually took up Diderot's challenge of 'applying' a pendulum to the mechanical organ, thus effecting the conflation of the 'deux machines distinctes'. ${ }^{53}$ Engramelle also advocated Diderot's system of calculating the number of seconds that a piece was meant to last, then determining the tempo by dividing the total time by the number of bars in the piece. ${ }^{54}$ In Engramelle's understanding, there was little room for personal interpretation of individual players in the performance of music: the composer's intentions were of paramount importance, and it was best to preserve them right down to the last second.

Just as the Jacquet-Droz automaton keyboard-player gave the impression of both mechanical ingenuity and human expression, Engramelle's technology, he argued, permitted the encoding and reproduction of both body and soul, which were encapsulated within the ideal performance of a composer. Composers' physical movements could be recorded in the manner and speed of their execution of a work. But, just as important, that ineffable and utterly essential component of French performance - its mouvement - could be preserved with astonishing exactness, since the precise placement (and displacement) of each note in time could be reflected in the notage for the creation of a pinned cylinder. What Couperin had described as 'l'esprit, et l'âme' of music - its spirit and soul, its humanity and expression - could now be captured and reproduced for generations.

A long tradition in France, some of which I have surveyed, confirmed that while freedom in musical performance, its mouvement, was essential, unruly performers also needed to be regulated by means of external machinery. The chronomêtre of Loulié and the métromêtre of d'Onzembray represented means of regulation, but the straitjacket that they imposed was too strict, even for Diderot, who was cynical in the extreme about the abilities of ordinary musicians. Engramelle combined the chronometric pendulum and the pinned cylinder, thus preserving the ideal performance: flexible in its mouvement, executed at exactly the right tempo, and fully in keeping with every

53 Although Arthur M. Wilson, in his study of Diderot, suggested that there was little connection between Engramelle's La tonotechnie and the Mémoires of Diderot on the same subject, it seems that Engramelle's treatise in fact took up the same themes and answered a number of the challenges that Diderot had issued. See Wilson, Diderot: The Testing Years, 1713-1759 (New York, 1957), 69.

54 'Il seroit donc à propos que les noteurs de cylindres aient chez eux une bonne pendule à secondes, pour s'assurer de la durée du mouvement de leurs cylindres \& de la longueur de leurs airs: c'est le moyen le plus sûr de fixer avec précision le tems nécessaire à la bonne exécution de ces airs.' Engramelle, $L a$ tonotechnie, 16. 
nuance of the performance style of the composer. La tonotechnie represented a musical culmination of eighteenth-century materialism - not as seen, but as heard. ${ }^{55}$

\section{Balbastre's Romance: La tonotechnie undone?}

Or such was the ideal. The results of Engramelle's project are, perhaps, more difficult to assess. They raise numerous questions related to aesthetics and performance practice, and, more broadly, authenticity and mediation, though the answers may be uncomfortably elusive.

Among Engramelle's crowning achievements was his collaboration with the composer Balbastre, which resulted in a notage of the latter's Romance published in nine elaborate illustrations in Bedos de Celles's treatise on organ-building, L'art du facteur d'orgues (1778). ${ }^{56}$ Bedos de Celles explained that he had been poised to begin work on his own essay on cylinder-pinning for automated organs when he happened upon Engramelle's La tonotechnie, and he thought it best to allow Engramelle to write this portion of the work. ${ }^{57}$ Engramelle took the opportunity to put into practice the sort of composer-artisan collaboration that he had advocated in La tonotechnie, and in his chapter in this later work he boasted of the success of this effort, claiming that

not only did [Balbastre] notate his piece on paper, as is seen engraved here, but he performed it many times, and his performance was followed with a watch that had a second hand. This is why one can be sure that the whole piece should not exceed 165 seconds. ${ }^{58}$

Balbastre's repeated performances of the piece would account for fluctuations in tempo, mouvement, articulation and ornamentation, resulting in a notage that captured an idealized performance of the piece. Although Engramelle did not cite Diderot by name, it seems clear that the method that Diderot had advocated in the 1740s - using a watch with a second hand to govern the speed of a pinned-cylinder organ - was the one that Engramelle used in this project.

55 In this context, it is worth considering Diderot's expression of radical materialism in his Lettre sur les aveugles à l'usage de ceux qui voyent (London, 1749), published just a year after his Mémoires. In this text Diderot's materialism took him as far as the articulation of moral relativism that led to his imprisonment. See George Makari, Soul Machine: The Invention of the Modern Mind (New York, 2015), Part 3: 'From French Esprit to Alienation'.

56 The Romance was published a year later as part of Balbastre's Sonates en quatuor, op. 3 (Paris, 1779).

57 See Bedos de Celles, L'art du facteur d'orgues, 596n.

58 'Non-seulement il s'est donné la peine de noter lui-même sa piece sur le papier, telle qu'on la voit gravée; mais il l'a exécutée à plusieurs reprises, \& son exécution a été suivie avec une montre à secondes à la main; c'est pourquoi on est en état d'assurer que sa piece entiere ne doit pas excéder la durée de 165 secondes.' Engramelle in Bedos de Celles, L'art du facteur d'orgues, 620. 
In his chapter Engramelle repeated a number of the principles - both aesthetic and practical - that he had laid out in La tonotechnie only a few years earlier. He outlined his lofty ambitions right from the start, describing the art of notage as 'a manner of conceiving of music that is totally different from that taught in all the treatises on this art; it is founded on performance itself' ${ }^{59}$ Machines, of course, could not be relied upon to cultivate le bon goutt, which meant that they would not know how to realize the mouvement of a piece of music that could only be implied in standard musical notation. The notage of a work thus demanded a level of specificity and attention to detail that was lacking in most scores, and in this sense it forced the composer and the artisan to overcome the obstacle that Couperin had described with such frustration: 'We write differently from the way we perform' (see above, p. 6). The cylinder-driven instrument could do no more and no less than it was programmed to do.

Although no pinned cylinder that preserves Balbastre's Romance in Engramelle's notage is known to survive from the eighteenth century, attempts have been made in the modern era to realize the notage in sound. Both the computer-generated recording made by Peter Gena and used by David Fuller in his study of Engramelle's technology and the 'educed-sound' realization made more recently by Patrick Feaster (sound clip 1) confirm that mouvement was an essential component of performance that Engramelle was able to capture in a way that was not possible in standard musical notation. ${ }^{60}$

A first hearing of sound clip 1 is jarring: the music sounds comical, almost disorientated. The treble melody has a degree of flexibility that is uncommon in contemporary performance, but the 'performance' sounds so much like the music of an organ-grinder at a carnival that it is difficult to take seriously. Can this really be the epitome of the great French style that Engramelle had in mind? Are contemporary ears so disconnected from eighteenth-century aesthetics and performance practice that we cannot recognize le bon goût when we hear it? Or was there, perhaps, something wrong with Engramelle's technology - something that prevented him from achieving his goal of conveying Balbastre's intentions faithfully?

In fact, as I will show in the discussion that follows, it was Engramelle himself who seems to have lost faith in this process. The technology did its job exactly as he designed it to do. But in transmitting the music from one agent (the composer) to another (the automated instrument), Engramelle consciously modified Balbastre's music: he altered the composer's articulation markings, thereby changing entirely the sonic result. A second hearing of sound clip 1 may be helpful here, as it enables us to

59 'Une maniere de concevoir la musique, toute différente de celle qu'on enseigne dans tous les traités de cet art; elle est fondée sur l'exécution même'. Ibid., 596.

60 Sound clip 1 may be accessed at <http://dx.doi.org/10.1080/02690403.2017.1286115>. Feaster's recording is on the album accompanying his book Pictures of Sound: One Thousand Years of Educed Audio: 980-1980 (Atlanta, 2012). The LP containing Gena's synthesized recording is difficult to find now, but this track is reproduced as an audio example in Haynes, The End of Early Music. 
tease apart two aspects of mouvement that seem to come into conflict. First, using the description of Couperin and the interpretation of McClary - namely that mouvement constitutes the music's 'particular way of inhabiting each successive beat' - I propose to consider the timing and placement of each note (whether it anticipates or lags behind the theoretical 'beat') separately from articulation (the amount of time occupied by sound as opposed to silence).

Engramelle, like the other French writers discussed here, insisted that flexibility in the placement of notes, suggesting a degree of nonchalance, was the key to good performance. On the subject of inégalité, for example, he wrote: 'This inequality should be varied according to the expression of the piece. [...] Taste - or rather, experience with notage - will make this difference apparent. ${ }^{61}$ His approach to inégalité and other fluctuations in placement matches descriptions by other writers of the eighteenth century: 'In happy pieces [the inequality] should be more marked than in pieces full of grace and with a tender expression. '62 In approaching a cadence as well, Engramelle claims to have captured Balbastre's flexible style in the most careful way:

Notating this cadence in this way [captures] the most common manner of M. Balbastre, for sometimes he prolongs this expansion of tempo a little, gradually, and other times he decreases it: the detail that I have shown in this expansion over the duration of a semibreve will suffice to indicate the means. ${ }^{63}$

And in ornamentation, flexibility is again essential: the speed of trills fluctuates with context and duration. These aspects of mouvement are indeed revealing, as other writers have remarked, for they shed important light on eighteenth-century French performance practice. ${ }^{64}$

61 'Cette inégalité doit varier suivant le genre d'expression de l'air. [...] Le goût, ou plutôt l'usage du notage, fera sentir cette difference.' Engramelle in Bedos de Celles, L'art du facteur d'orgues, 602. Arthur W. J. G. Ord-Hume concurs that experience with notage would substitute for musical training in the artisans responsible for pinning the cylinders for mechanical keyboards. See Ord-Hume, Joseph Haydn and the Mechanical Organ (Cardiff, 1982), 104-5.

62 'Dans les airs gais, elle doit être plus marquée que dans les airs gracieux \& d'une expression tendre.' Engramelle in Bedos de Celles, L'art du facteur d'orgues, 602.

63 'En notant ainsi cette cadence, elle sera dans le genre le plus ordinaire de M. Balbastre; car il arrive quelquefois qu'il prolonge un peu plus cette augmentation graduée de vitesse, \& d'autres fois qu'il la diminue: le détail que j'ai fait ici de cette augmentation pendant la durée totale d'une blanche, suffira pour indiquer le moyen.' Ibid., 632.

${ }^{64}$ See, for example, David Fuller, 'Mechanical Musical Instruments as a Source for the Study of "Notes inégales", Bulletin of the Musical Box Society International, 20 (1974), 281-93 (pp. 287-90); Arthur W. J. G. Ord-Hume, 'Ornamentation in Mechanical Music', Early Music, 11 (1983), 185-93 (pp. 192-3); Houle, Meter in Music, 122; and Haynes, The End of Early Music, 148. See also Dirk Moelants, 'The Performance of Notes inégales: The Influence of Tempo, Musical Structure, and Individual Performance Style on Expressive Timing', Music Perception: An Interdisciplinary Journal, 28 (June 2011), 449-60. 
However, the left-hand articulation is more problematic. It is executed in the same detached manner in both Gena's and Feaster's realizations, and it calls into question both Engramelle's claims to represent Balbastre's intentions and the project of $\mathrm{La}$ tonotechnie as a whole. What is striking about these sound realizations is the extent to which each note of the left-hand accompaniment is detached from the notes around it. George Houle and Fuller both remarked on this problem: Houle characterized Engramelle's notage as 'overly mechanical', suggesting that nuanced articulation was 'beyond the capability of the serinette' ${ }^{65}$ Fuller, admitting that a barrel organ should in theory be able 'to reproduce every nuance of which a harpsichordist's or organist's fingers are capable', wondered why the release of each note is everywhere 'almost instantaneous'. Yet he also accepted at face value Engramelle's claim that 'we have, in the matter of articulation at least, a direct link between the analysis of a playing style and its realization on cylinders' ${ }^{66}$ It is this point that I wish to consider more closely now.

Engramelle took numerous paragraphs - both in La tonotechnie and in L'art du facteur d'orgues - to justify his approach to articulation. He wrote that

all notes have two essential constituent parts, which are the sound [tenue, 'holding'] and the silence. [...] These should [both] be captured exactly in the notage; in this way one must express the value not only of the part of each note that speaks, but also their silences, which serve to detach them to create articulation in music, and without which [the music] cannot but produce a poor effect, similar to a musette, of which the most appalling defect is that it has no articulation. ${ }^{67}$

He admitted that the length of the silence should be varied according to the emotional content of the music, and indeed he wrote of Balbastre's piece that 'this Romance, being of a gracious expression, should be less detached than other, ordinary pieces; this is why the silences at the end of each note should be less short than in pieces [with a] detached [execution]'. ${ }^{68}$ But even in pieces with a 'tender expression', he claimed, some articulation was still necessary after every note; 'no note is exempt' ${ }^{69}$

65 Houle, Meter in Music, 122.

66 David Fuller, 'An Introduction to Automatic Instruments', Early Music, 11 (1983), $164-6$ (pp. 165-6).

67 'Toutes les notes ont deux parties essentiellement constitutives, qui sont la tenue \& le silence. [...] Elles doivent être appréciées avec exactitude dans le notage; ainsi il faut exprimer la valeur, non-seulement des parties parlantes de chaque note, mais celle de leurs silences, qui servent à les détacher pour former l'articulation de la musique; \& sans lesquelles, elle ne produiroient qu'un mauvais effet, semblable à celui d'une musette, dont le défaut le plus choquant est de n'avoir aucun son articulé.' Engramelle in Bedos de Celles, L'art du facteur d'orgues, 597.

68 'Cette Romance étant d'une expression gracieuse, elle doit être moins détachée que dans les pieces ordinaires; c'est pourquoi les silences à la fin de chaque note doivent être moins courts que dans les pieces détachées.' Ibid., 623.

69 'Aucune note n'est exempte.' Ibid., 600. 


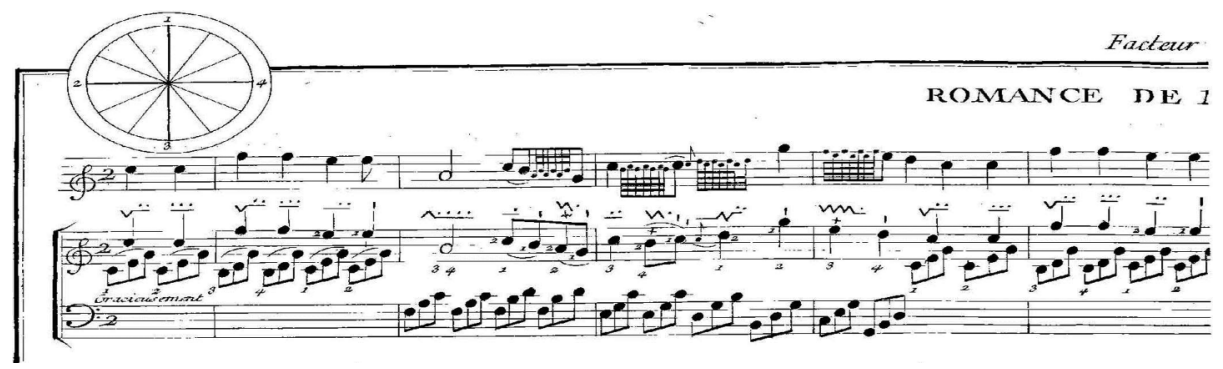

Figure 4. Detail of François Bedos de Celles, L'art du facteur d'orgues ([Paris], 1778), plate 119, showing the opening of Balbastre's Romance in standard musical notation and in Engramelle's shorthand for the artisan pinning a cylinder. Note the slurs over the groups of triplet quavers in the left hand.

Indeed, Engramelle made a special point of altering the articulation left by Balbastre. Whereas Balbastre had written a slur over each group of three triplet quavers, each group outlining a distinct harmony (see Figure 4), Engramelle replaced these with the sharpest articulation he could. He placed a vertical line, which he called a tactée, over each triplet quaver note (Figure 5 a shows the complete page; Figure $5 \mathrm{~b}$ shows the detail with the tactée articulation). As he explained in La tonotechnie,

The character that indicates the ordinary tactée is the same that musicians use to mark a detached note. [...] I have preferred to use the term tactée over détaché for these notes, because it seems to me more expressive, in that [these notes], described in this way, allow nothing to be heard but the striking of the note - that is to say, a very short sound at the beginning of the note, the rest of which is consequently in silence. ${ }^{70}$

To convince his readers of the need for this detached articulation on every note, Engramelle challenged his reader to play 'on an organ, a harpsichord, a spinet, or any other keyboard instrument, whatever piece he wishes', and to pay attention to the articulation: he claimed that the finger 'is often lifted long before the finger plays the next note $[\ldots]$ now if [the player] pays careful attention, he will find between every note, some spaces - more or less long - without which the execution will necessarily be poor ${ }^{71}$ Likening silences to the consonants of speech, Engramelle claimed that

70 'Le caractère qui indiquera la tactée ordinaire, est le même que celui des musiciens pour marquer les détachées. [...] J'ai préféré à me servir du terme de tactée à celui de détaché, pour ces notes, parce qu'il m'a paru plus expressif, en ce qu'elles ne laissent pour ainsi dire appercevoir que le tact de la note, c'est-à-dire, un son très-court dans le commencement de la note dont le surplus reste conséquemment en silence.' Engramelle, La tonotechnie, 38-9.

71 'Sur un orgue, un clavecin, epinette, ou tout autre instrument à clavier que ce soit, tel air qu'on voudra'; 'est souvent levé long-temps avant qu'on ne pose le doigt sur la note suivante [...] or si l'on y prend bien garde, il se trouvera entre toutes les notes, de ces intervalles plus ou moins longs, sans lesquels l'exécution seroit nécessairement mauvaise'. Engramelle in Bedos de Celles, L'art du facteur d'orgues, 600 . 


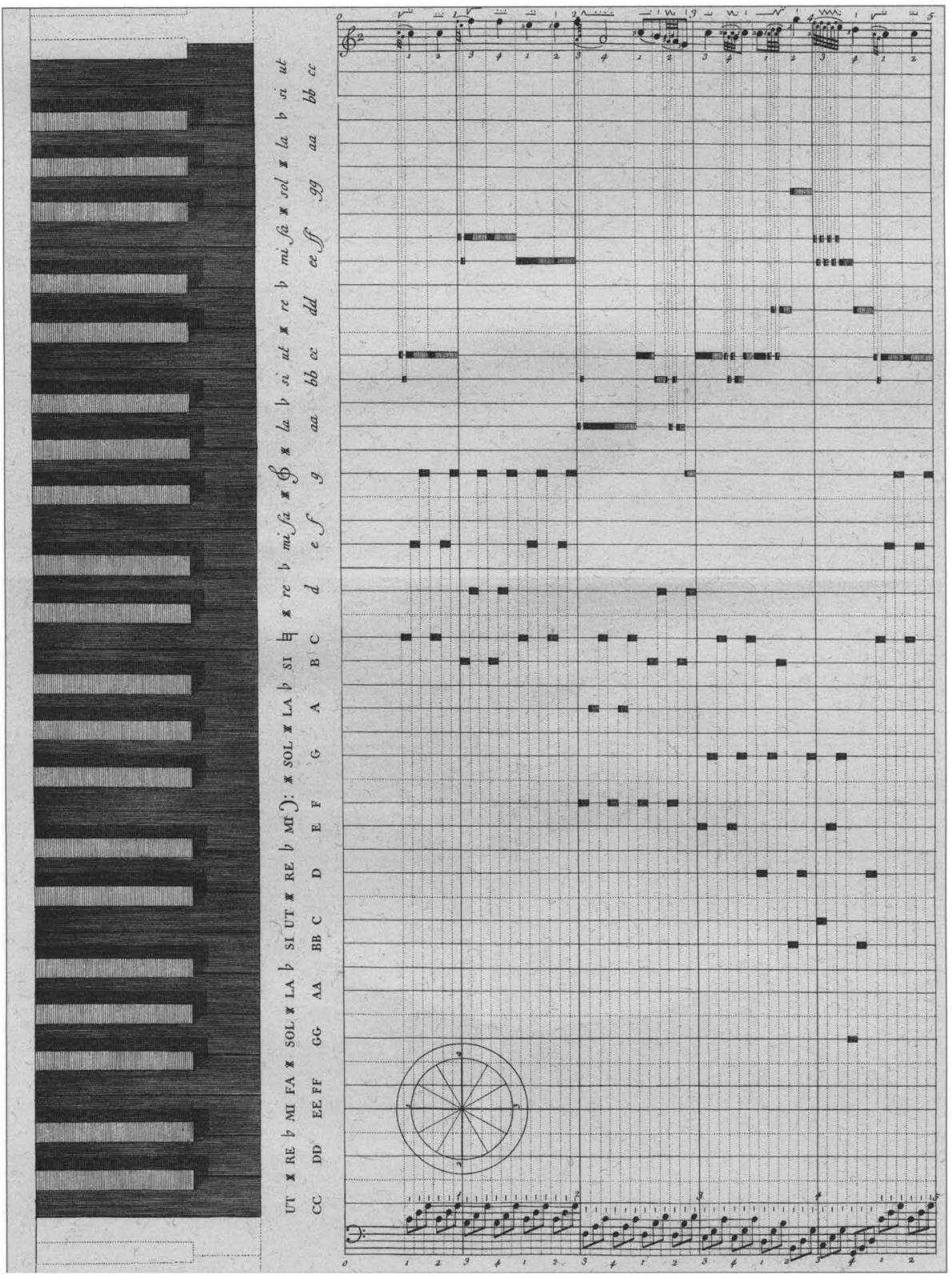

Figure 5a. François Bedos de Celles, L'art du facteur d'orgues, plate 120, showing Engramelle's notage for Balbastre's Romance. The slurs have been replaced by his vertical strokes known as tactées. 


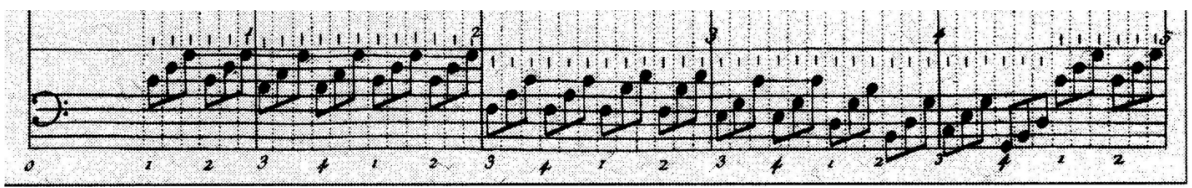

Figure 5b. Detail of François Bedos de Celles, L'art du facteur d'orgues, plate 120.

without a silence after each note, 'the syllables would have no more distinction than the sound of unarticulated vowels'.$^{72}$

While there is ample evidence that the basic articulation of the eighteenth century was a detached one, ${ }^{73}$ the vast majority of sources on French execution stand in opposition to Engramelle's position on this accompanimental figure. Slurs over accompanimental harmonic groupings would imply a highly connected execution, and perhaps even an 'over-legato', in which notes are held longer than their notated value, to provide a rich harmonic foundation for the melody. In the words of Rameau (a much more experienced keyboardist than Engramelle), 'A slur that embraces many notes indicates that one must hold them all down from one end of the slur to the other. ${ }^{74}$ The silence would occur only at the end of the slur. This view was echoed by writers throughout the eighteenth century. I have tried to illustrate this sort of execution as applied to Balbastre's Romance in sound clip $2 .^{75}$

Where does this leave us? Is it possible that Engramelle exaggerated the extent of Balbastre's involvement in the preparation of the notage for the Romance? Alternatively, could Balbastre have made himself available to embark on this musical experiment with Engramelle, not taking it seriously as a true representation of his art? Could he have judged this automated technology to be a curiosity, in the same way that Diderot viewed the automata of Vaucanson? Or could the composer have been willing to play for Engramelle but have neglected to follow up by listening to the sonic result? Finally, is it possible that no sonic product was ever produced, and instead, that the notage for the Romance remained inscribed silently in a book - an artwork unto itself? Engramelle wrote that the piece 'was reviewed by [the composer] himself', and that Balbastre

72 'Les syllables n'auroient d'autre distinction que le son inarticulé des voyelles'. Engramelle in Bedos de Celles, L'art du facteur d'orgues, 600.

73 See the sources in Rosenblum, Performance Practices in Classic Piano Music, Chapter 5: 'Articulation and Touch' (pp. 144-89).

74 'Une liaison qui embrasse plusieurs notes, marque qu'il faut les tenir toutes d'un bout de la liaison à l'autre.' Jean-Philippe Rameau, Pièces de clavecin, quoted and trans. in Yonit Lea Kosovske, Historical Harpsichord Technique: Developing La douceur du toucher (Bloomington, IN, 2011), 88 and 172.

75 Sound clip 2 may be accessed at <http://dx.doi.org/10.1080/02690403.2017.1286115>. My performance represents an attempt to synthesize information about timing, articulation and ornamentation from Engramelle's notage, from Balbastre's published version, which appeared in the following year, and from my experience with eighteenth-century music, performance treatises and instruments. I make no claim that this is a 'correct' performance - only that it represents an alternative to what I hear as Engramelle's overly articulated rendering. 
confirmed that 'it is in his true manner of performance' ${ }^{76}$ But it seems possible that the composer was only looking at the notage - not hearing the musical result.

Perhaps the most likely answer is that Balbastre's collaboration with Engramelle, like La tonotechnie itself, was a public performance in the science and technology of music, a thought experiment that sought to pique the curiosity of readers and listeners even as it tested the implications of automated technology for musical practice. Engramelle lamented the fact that so few great composers knew how to apply La tonotechnie to preserve their music. But Engramelle himself was not a composer or musician of any renown, and the aesthetic result of his effort raises as many problems as it answers. Whatever the motivations - philosophical, musical, scientific or commercial that lay behind his efforts to preserve musical practice through this mechanical technology, musical texts and performances remained mired in the messy subjectivity of players, listeners, technologists and composers. Like other thinkers of the French Enlightenment, Engramelle chased the chimera of certain knowledge, but 'l'esprit, et l'âme' of French music remained as elusive as ever.

\section{ABSTRACT}

Marie-Dominique-Joseph Engramelle's treatise La tonotechnie, ou l'art de noter les cylindres (1775) claimed that automated instruments driven by pinned cylinders would grant listeners direct access to music as the composer conceived it. Standard notation was insufficient, as it did not capture the music's mouvement - its temporal flexibility from moment to moment. Denis Diderot provided an aesthetic justification for automated instruments in terms that linked them to materialist philosophy. Like android automata, which simulated life through automated motion, automated musical instruments encoded live music to simulate the ideal performance of a composer. Yet Engramelle's collaboration with the composer Claude Balbastre, which resulted in a pinned-cylinder notage of one of Balbastre's keyboard pieces, raises crucial questions about the effectiveness of the technology and its notation, and about Engramelle's claims and his own musical skill. Engramelle's project is best understood as a performance unto itself - a manifestation of the cultures of public science that were widespread in the European Enlightenment.

76 'Revue par lui-même'; 'elle est dans son vrai genre d'exécution'. Engramelle in Bedos de Celles, L'art du facteur d'orgues, 620. 